\title{
3R philosophy for sustaining recreational attractiveness and development of hotel business in Ukraine
}

\author{
Olena Sushchenko ${ }^{1}$, Olena Prokopishyna $^{2}$ and Natalia Kozubova ${ }^{11}$ \\ ${ }^{1}$ Simon Kuznets Kharkiv National University of Economics, Department of tourism, 61001 Kharkiv, \\ Ukraine \\ ${ }^{2}$ Simon Kuznets Kharkiv National University of Economics, Department of accounting and business \\ consulting, 61001 Kharkiv, Ukraine
}

\begin{abstract}
The paper highlights the problem of waste accumulation and ways of its solution. It was established that landfills occupy $7 \%$ of the total territory of Ukraine and their area is larger than the area of natural reserve funds. Based on the dynamics of garbage accumulation the paper forecasts increase solid household waste in geometric progression. The article shares experience in field of utilization and waste management and grounds the necessity of separating rubbish into fractions and processing each component that is sold separately on the market. It is proposed to use a systematic approach to waste management in hotel business. The paper justifies the conclusion that only the proliferation of 3R philosophy - Reuse-Reduce-Recycle - in behaviour of tourists and the local population in everyday life will preserve the recreational attractiveness of Ukraine and provide the basis for the development of hotel business.
\end{abstract}

\section{Introduction}

Economic growth affects all aspects of human life, including production and consumption, which, in turn, leads to an increase of waste. This problem is especially vivid for developing countries, where environmental laws are not yet fully formed, and acceleration of economic development is being accompanied by the deterioration of the environment. Experts of the Organization for Economic Cooperation and Development (OECD) have calculated that a $1 \%$ growth in the national income increases the solid domestic waste by $0.69 \%$ [1]. In addition, the composition of waste is changing: the number of urban food waste is increasing (by $44 \%$ between 1995 and 2013), the share of complex waste (electronic, nanomaterials, household goods) also increases. According to World Bank forecasts, in 2025, city dwellers will produce an average of $1.42 \mathrm{~kg} /$ person of solid household waste per day compared with the current 0.64 $\mathrm{kg}$. The total amount of waste generated by residents of cities will increase from 0.68 to 2.2 billion tons per year. As for most developing countries, the problems of waste management appeal to be quite acute for Ukraine.

${ }^{1}$ Corresponding author: kozubova_natali@ukr.net 
Despite economic fluctuations in Ukraine, in recent years the process of waste accumulation has continued as a result the lack of a concept for efficient utilization at the state level. The environmental situation around the cities is worsening (especially with a population exceeding 1 million inhabitants), hazardous landfills emerge throughout the country, hurt ecology situation and tourism attractiveness, hamper development of hotel business.

\subsection{The relevance and the problem of the research}

As the cost of raw materials is high and increases it is irrational, both from an economic and an environmental point of view, to underground raw materials which are suitable for reuse. The main problem with the use of raw material is its removal from the funny mass, because it is almost unusable for recycling. Therefore, with the improvement of the system's technical sorting, deductions are worked out. For this economic policy, legal measures, agitation and propaganda among the population should be carried systematically.

The purpose of this research is to analyze existing waste problems and develop methodical approaches for waste management for preserving recreational suitability and ensuring the sustainable development of the hotel business.

\subsection{Literature Review}

Different countries apply many approaches to implementing the concept of waste disposal. In developed countries, garbage is recycled and reused. Waste is returned to the state of raw materials and is being processed by enterprises. Michael Hiete, Julian Stengel, Jens Ludwig and Frank Schultmann highlighted due to economic development demand increases as well as consumption and therefore the accumulation of waste accelerates, so only re-use of materials can reduce the burden on the environment [2].

Under the concept of full waste utilization, the multi-stage process of sorting and recycling of garbage, which minimizes the amount of waste at disposal, maximizes economic efficiency and minimizes the impact on the environment. As Nadim K. Copty, Didar Ergene and Turgut T. Onay note, the consumer pays for the disposal of garbage [3]. The cost can be paid separately (for example, utilities) or included in the price of the goods. Paul Isely and Aaron Lowen in their work emphasize that a very important factor in the development of the waste recycling industry are pricing and tariffs for the export and sorting of rubbish [4]. In many countries, citizens pay a certain amount of money for the collection and utilization of rubbish, which is included in the payment for utilities. Another approach is that garbage recycling is handled by the company's producers, but the cost of recycling is also translated into the consumer and is reflected in the price of the product.

\section{Results and discussion}

Most countries of the world have been confidently reducing the amount of solid domestic waste for several decades, while Ukraine, despite a number of laws, such as "On Waste" and "On Environmental Protection", continues to bury them at landfills and burn them, which has a negative impact. to the environment. Handling solid domestic waste threatens Ukraine with an environmental problem due to their complex environmental impact and environmental safety. In 2017, it was formed 366,054.0 thousand tons. domestic waste and waste from economic activity, and this indicator has significantly increased after a few years of decline. Today, 12,442.2 million tons are in places of waste disposal [5].

According to the statistics of Ukraine, there is a tendency to decrease the amount of waste in recent periods (Table 1), but the reason for this is the difficult political situation in the regions, 
which at the moment are not reflected in the reports, therefore for the forecast the data from 2010 to 2013 should be adjusted by corresponding amount of generated waste in these regions.

Table 1. Dynamic of the wastes generation, thousand tons

\begin{tabular}{|c|c|c|}
\hline Year & Official statistic values & Adjusted values \\
\hline 2010 & 419191.8 & 344083.1 \\
\hline 2011 & 447641.2 & 363539.8 \\
\hline 2012 & 450726.8 & 373360 \\
\hline 2013 & 448117.6 & 374128.3 \\
\hline 2014 & 354803 & 354803 \\
\hline 2015 & 312267.6 & 312267.6 \\
\hline 2016 & 295870.1 & 295870.1 \\
\hline 2017 & 366054 & 366054.0 \\
\hline
\end{tabular}

Polynomial model (Figure 1) has the best approximation value, the rate of determination ensure that forecast is quite accurate. Predictive values demonstrate that official statistic tends to conceal waste problems while adjusted data reveal inevitable increase in the amount of solid household waste in a geometric progression in future.

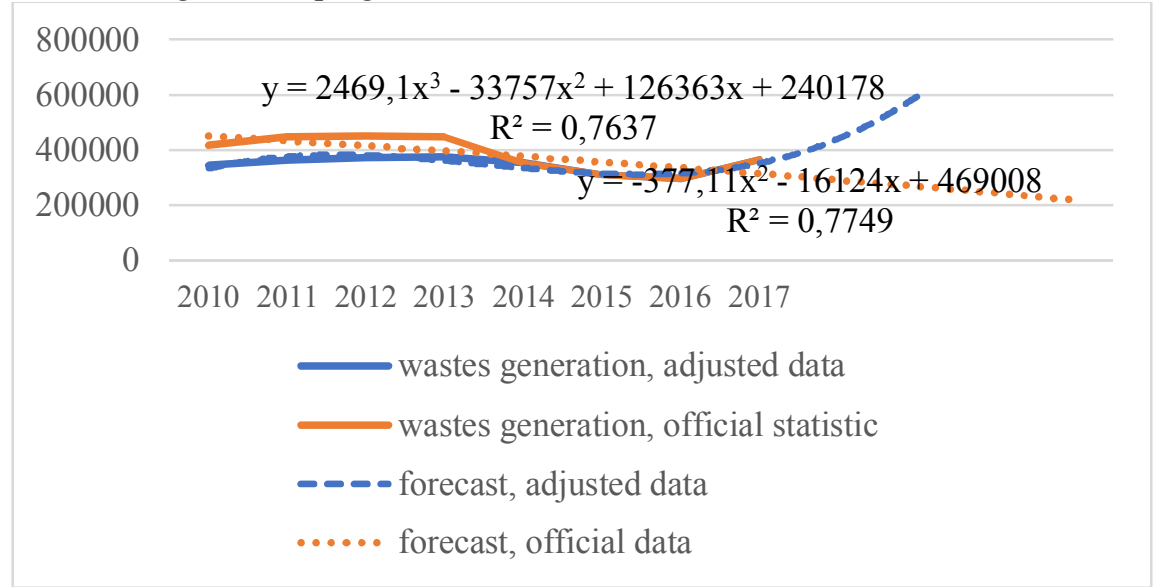

Figure 1. Forecast for waste generation in Ukraine for the period of 2019 - 2022

The constant increase in the amount of generated waste leads to an increase in the seizure of valuable, recreationally, land for burial grounds and loss of resource and value components, while Ukraine increases the import of re-raw materials. In 2017, the amount of imported waste paper increased by $27 \%$ compared with 2016 (346.4 thousand tons versus 271.9 thousand tons), during the 4 months of 2018 by 30\% (130 thousand tons versus 99.9 thousand tons tone). Imports of secondary polymer materials in 2017 grew by 2.6 times compared to 2015 (38.6 thousand tons vs. 15.1 thousand tons in 2015), and in 2018, the import of these wastes is expected in volume of 48,0 thousand tons, which is 1,5 times more than in 2017 [5].

Excessive import of waste has led to a significant collapse of domestic specialized enterprises, since the recycling of waste paper and secondary polymer materials from domestic suppliers to processing enterprises is limited, and for certain types - discontinued. The warehouses of the enterprises are crowded with sorted waste paper and secondary polymer materials. Collection and harvesting of these types of secondary raw materials is limited, and some enterprises are discontinued. 
Unnecessary domestic waste paper and waste from plastics continue to replenish unauthorized dumps, clog up forest parks, forest plantations, yards of cities and villages of Ukraine.

An increase in the import of secondary raw materials into the territory of Ukraine jeopardizes the fulfillment of the tasks set by the National Waste Management Strategy in Ukraine, namely, the introduction by 2023 of 2,500 settlements for the separate collection of waste, which are suitable for reuse and recycling [6].

In accordance with the Law of Ukraine "On Waste" a mandatory separate collection of household waste is established. General provisions for separate collection household waste are specified in the Method separate collection household waste, approved by the order of the Ministry of Regional Development as of 01.08.2012 number 133, which defines the general aspects of the implementation separate collection system. Separate collection household waste, including hazardous waste in their composition, is carried out by waste holders in accordance with waste legislation. At the same time, the selection of recycled raw materials from household waste collected in containers or loaded with garbage can only be allowed at specialized waste sorting and processing enterprises in accordance with waste legislation. At present, there is no normative act that clearly and transparently defines the legal relationship (rights, responsibilities, responsibilities) of all participants in the process of implementation of separate collection of household waste, including its sorting.

In 2017, a small number (822) of settlements in Ukraine introduced a separate collection household waste. There are 25 garbage collection lines in 20 settlements, including 6 in Kyiv. However, it's still too early to state the success of sorting. For example, we can consider the proportion of settlements where separate collection of solid waste is implemented, in relation to the total number of settlements in this region in 2017: in Vinnytsya oblast - 2.9\%; in Zhytomyr $1 \%$; in Odesa - $0.3 \%$; in Kharkiv - $10.9 \%$; in Kyiv $-2.8 \%$.

\section{Recommendations}

Only the proliferation of the 3R philosophy - Reuse, Reduce, Recycle - in everyday life and at business will preserve the recreational appeal of Ukraine.

Reuse means the opportunity to use things again, or to find a new consumer. Organic waste can be turned into composted fertilizer, old clothes may be taken to a shelter. Reduce means lower consumption. This is a decrease in the number of things used in everyday life, the first and most important step on the way to saving Ukraine from garbage. Unnecessary packaging of consumer goods should be avoided. Recycle means reprocess materials, for instance, recycled aluminium bottle need $80 \%$ less electricity than new ones.

Consequently, the existing waste management practices do not allow for the economic potential reuse of resources and reduce the burden on the environment. Most of the existing landfills are morally and physically obsolete and will not be able to absorb growing waste volumes in the long run and ultimately lead to serious environmental impacts.

In Ukraine, there are 6,148 landfills, of which only 2,600 are certified. The area of landfills is $7 \%$ of the total territory of our country and is larger than the area of the natural reserve fund; 32,984 dumps are unauthorized.

The efficiency of the end result of disposal depends to a large extent on the implementation of the principles of a systematic approach, which should include: a gradual reduction the total amount of domestic waste generation in human settlements; a sharp decrease in the amount of landfill disposal at landfills and the transition to waste recycling technologies; coverage $100 \%$ of settlements by collection and removal household waste; introduction of waste sorting in the settlements of the region; liquidation, sanation, reclamation of unauthorized landfills and closed 
landfills; consolidation of existing polygons and their transformation into regional ones in accordance with current environmental and sanitary requirements; creation of new production facilities for the sorting and processing household wastes and selected secondary raw materials; creation in the regions network of sorting and processing enterprises for the processing of all components household waste by modern advanced technologies; creation of preconditions for the complete collection, removal and recycling household waste with the placement land only on the landfills that are not processed, inert to the environment .

The social and responsible attitude of the hotel and tourist business to the problems of domestic waste management is very important, as tourist enterprises, on the one hand, are "producers" of sufficient quantity of resource-valuable waste, and on the other hand their activity depends on the environment state. Today, the concept sustainable development of tourism involves focusing on the understanding its environmental impacts and the development more sustainable forms its development to preserve the basic natural and socio-cultural resources of the environment.

Among the tourism sub-sectors, the hotel business has a significant impact on the environment. This sphere consumes a significant amount of energy, water, chemicals, produces a significant amount household waste. The adverse impact on the environment increases and deepens. Such enterprises partially or completely do not utilize waste, use wood for fuel from the surrounding area, dispose untreated sewage into the rivers, develop additional services that are oriented towards the active use the environment.

Substantial damage causes pollution by household waste, the source of which is the place of the longest tourists stay - accommodation establishments [7]. In addition to the deteriorating aesthetic appeal of the territory, household rubbish threatens the existence many representatives of the fauna. Animals undergo changes in behavioural reflexes, chemical additives and gene modulators in food waste cause impairment of immunity and genetics, poisoning and death. The problem of environmental pollution with household rubbish is especially relevant for hotels, separated in hard-to-reach places, which causes uncontrolled violation the waste management rules. Solid household waste is spontaneously stored in unsuitable places for this purpose, with non-compliance with environmental standards of utilization. Local landfills polarize the scale of the problem of pollution by dispersing garbage by the wind, falling into surface and groundwater. Unique natural conservation and recreational areas are particularly exacerbated by this problem [8].

The nature and consequences of the impact of the hospitality infrastructure are due to the object location of natural or socio-cultural interest. Subjects with a socio-cultural organization higher level are significantly less negatively affected. Such objects provide an effective stay of visitors, maintain an appropriate comfort level, and at the same time organize structures for limiting negative environmental impacts. In addition to utilizing the products of the activity, limiting the impact on the surrounding area by limiting recreational and tourist activities (buffer forest park areas, protected areas, monitoring the status of individual natural objects, etc.). In addition to the spatial sign of the hospitality impact on the environment, it is necessary to take into account the temporal phenomenon identified in the peculiarities of tourism development seasonality. Most hotels, especially with the active use natural resources of the surrounding area (resort hotels, tourist hotels, tourist shelters), have a profound effect on ecosystems during a certain part of the year, in other seasons it is possible to restore it. Thus, the effect is temporary and coincides with the tourist season (skiing, beach, mountaineering) or long-term, with irreversible ecological changes - the disappearance certain species of the organic world or generally biocenoses. An important feature of hospitality is the nature of the relationship with the environment - technological. Hotel establishments for the most part provide a continuous mode of operation with an average load of $60-80 \%$. Despite the application of the latest technologies, special equipment for saving energy, water, chemicals, hygiene products, food and other resources, their use remains significant. 


\section{Conclusions}

On the basis of the conducted research it can be concluded that there is regularity in the rate of growth of waste accumulation over time. Since the total amount of waste is not utilized, the amount of waste steadily increases. Together with the increase in the amount of garbage, the area at which landfills are located, are increasing by 160 hectares per year. By 2022, the projected square of landfills will exceed 1 million hectares.

According to the results of the study, it was found that the lack of developed infrastructure for the collection, removal, recycling of household waste, lack of awareness of society about the need to sort household waste by their separate components, which are secondary raw materials, is hindered by the implementation of separate collection of household waste. The main factors contributing to this situation are non-fulfillment by local self-government bodies of the requirements defined by the Laws of Ukraine "On Housing and Communal Services" and "On Waste" as part of the insufficient organization of separate collection of useful components of household waste.

The use of $3 R$ philosophy in the hotel business is especially relevant for Ukraine, as it contributes not only to the acquisition of additional customers advocating for ecology. Such objects provide an effective stay of visitors, maintain an appropriate level of comfort, and at the same time organize structures for limiting negative environmental impacts. In addition to the utilization of products, 3R philosophy decrease the impact on the surrounding area by limiting recreational and tourist activities due to establishment of buffer forest park areas, protected areas and monitoring the status of individual natural objects.

\section{References}

1. Organisation for Economic Co-operationand Development, OECD http://www.oecd.org (2019). Accessed 30 Mar 2019

2. Hiete, Michael, et al. "Matching construction and demolition waste supply to recycling demand: a regional management chain model.” Building Research \& Information 39.4 (2011): 333-351.

3. Copty, Nadim K., Didar Ergene, and Turgut T. Onay. "Stochastic model for landfill gas transport and energy recovery." Journal of Environmental Engineering 130.9 (2004): 1042-1049.

4. Isely, Paul, and Aaron Lowen. "Price and substitution in residential solid waste." Contemporary Economic Policy 25.3 (2007): 433-443.

5. State Statistics Service of Ukraine. http://www.ukrstat.gov.ua (2019). Accessed 22 Mar 2019

6. Solid domestic waste in Ukraine: Potential for developing scenarios for the development of the solid waste management industry. URL:https://www.ifc.org/wps/w952.S (2019). Accessed 22 Mar 2019

7. Sushchenko, O., Prokopishyna, O., \& Kozubova, N. Eco-Friendly Behaviour of Local Population, Tourists and Companies as a Factor of Sustainable Tourism

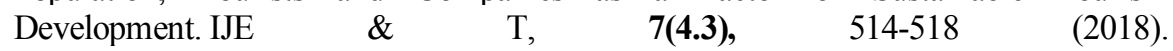
doi:http://dx.doi.org/10.14419/ijet.v7i4.3.19926

8. O. Prokopishyna, N. Kozubova Organizational support for internal tourism based on rational use of Ukraine tourist and recreational resources, NVIU 13, 54 (2015) 